\title{
The heterogeneous effect of democracy, economic and political globalisation on renewable energy
}

\author{
Oleksiy Lyulyov ${ }^{1}$, Tetyana Pimonenko ${ }^{1 *}$, Alexey Kwilinski ${ }^{2}$, and Yana $\mathrm{Us}^{1}$ \\ ${ }^{1}$ Department of Marketing, Academic and Research Institute of Business, Economics and Management, \\ Sumy State University, Rymskogo-Korsakova st. 2, 40007 Sumy, Ukraine \\ ${ }^{2}$ The London Academy of Science and Business, Baker St. 120, W1U 6TU, London, England
}

\begin{abstract}
This paper summarises the arguments and counterarguments within the scientific discussion on international cooperation's role in combatting climate change and its impacts. The primary purpose of the research is to determine renewable energy development reliance on democracy and globalisation levels. The objects for analysis are Ukraine and countries with different democracy regimes: full democracy (Finland, Denmark, Spain), flawed democracy (Poland, Slovakia, Hungary, and the Czech Republic) and hybrid democracy (Ukraine, Turkey and Montenegro). To gain the research goal, the authors examined data on the share of renewable energy, GDP per capita, labour force and gross fixed capital formation from 2012 to 2019. The data was retrieved from the Eurostat database, World Data Bank, KOF Swiss Economic Institute and the Economist Intelligence Unit. The following methods and tests were used: Levin, Lin, and Chu test; Augmented Dickey-Fuller Fisher and PhillipsPerron Fisher unit root test; Im, Pesaran, Shin's panel unit root tests. The authors used the Pedroni test to cointegration among variables. The Fully Modified OLS and Dynamic OLS panel cointegration techniques were applied to evaluate a statistically significant longer-term relationship between variables. The findings confirmed that for countries with the hybrid regime, the changes in political and economic globalisation provoked the rapid growth of renewable energy compare with countries from full and flawed democracy.
\end{abstract}

\section{Introduction}

Nowadays, international climate change commitments are on the agenda. The pointed question is to mitigate and adapt to adverse climate changes while decreasing human health and environmental risks and providing global economic, social, and energy preparedness. The urgent action to combat climate change and its impacts need international cooperation. It stands to mention that the climate consensus is expressed by the several signed international agreements such as the United Nations Framework Convention on Climate Change, Kyoto Protocol to the UN Framework Convention on Climate Change, Paris climate agreement, etc.

\footnotetext{
* Corresponding author: tetyana_pimonenko@econ.sumdu.edu.ua
} 
In December 2019, the EU Council presented the European Green Deal (EGD) to achieve a carbon-free economy with net-zero greenhouse gas emissions until 2050. Green energy transition drives the energy-efficient potential, renewable energy sources and green transport, circular economy development, carbon capture and storage, smart network services, the extension of bioenergy etc.

EGD opens the window of opportunities for global energy collaboration to boost economic growth. It should provide a positive energy balance, gain energy independence, create fair competition in the energy market, increase the share of energy generations from renewable sources, develop a proportional energy tariffs policy, etc. To be an active actor of global combating climate change, different countries have accepted the Paris Agreement Goals in reliance upon national strategies and priorities. However, many countries are falling behind in the case of their National Energy and Climate Plans.

Nowadays, the pandemic challenge opened new opportunities to renovate the economics sustainably. Green energy transformation is considered to be a vector toward energy independence. Energy efficiency and renewable energy sources are the determinants attributes of economic growth. Thus, energy-efficient advance allows a considerable decline in the different energy generation for GDP growth and social welfare. It triggers all-electric economy development by renewable energy share gains and reduces fossil fuel consumption. Thus, advance in energy efficiency and renewable energy are global priority orientations.

It worth noting that GDP energy intensity is on a downtrend. However, it is still high, especially for Ukraine. Figure 1 shows that, in 2019, the global total energy consumption per unit of GDP decreased by $26.2 \%$ compared to 2000 , while in Ukraine - by $56.3 \%$ [2]. However, in 2019, Ukrainian GDP energy intensity was by 2.11 times compared to the global level. In turn, in Poland (one of the biggest trade partners of Ukraine), the level of GDP energy intensity was lower by 2.7 times in 2019 .

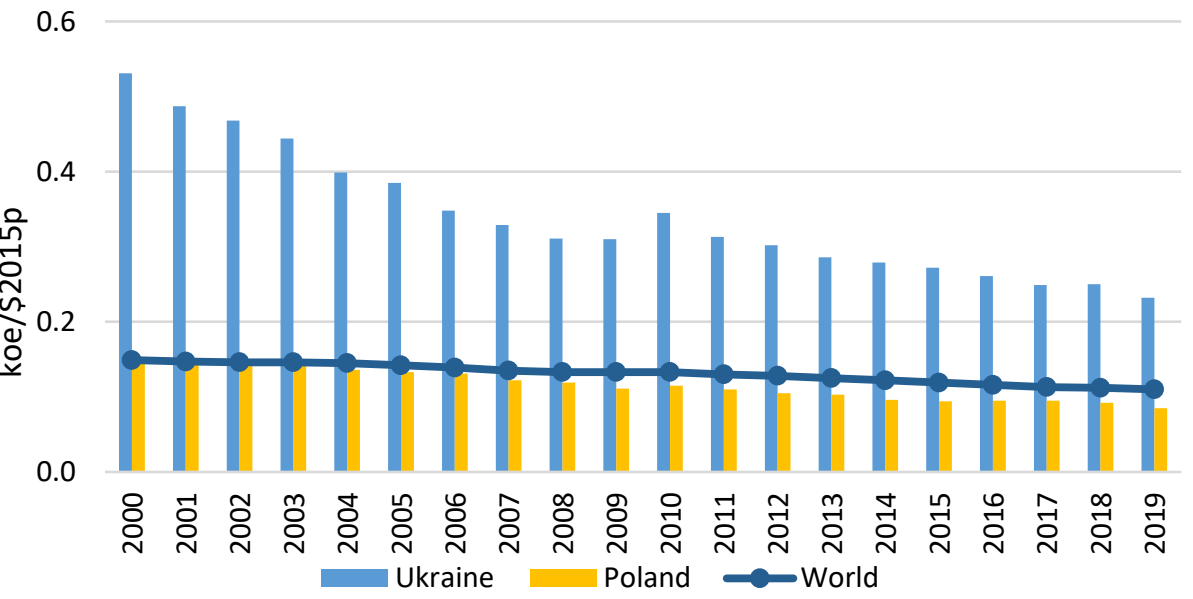

Fig. 1. Energy intensity (total energy consumption per unit of GDP), 2020-2019

*Source: compiled by the authors based on the data [2].

The analysis of statistical data showed that Ukrainian total energy consumption per unit of GDP is stratospheric. Therefore, the green energy transition requires massive investments and expenditures in energy and consumer sectors to increase energy efficiency by implementing new technologies in production, transportation, and energy consumption. Notably, renewable energy sources are considered the most powerful instrument in decarbonising the national and global economies. 


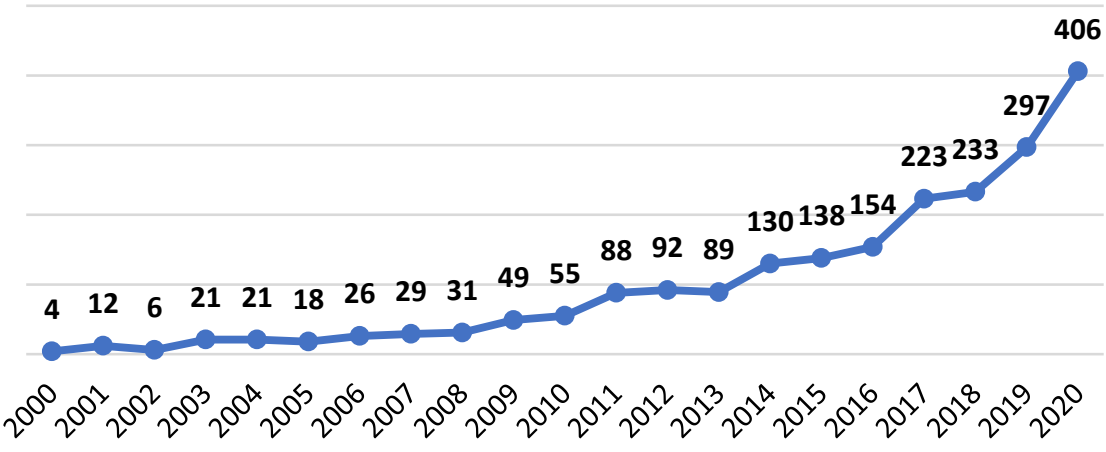

Fig. 2. Publication activity o "renewable energy" and "economic growth", 2000-2020 Source: developed by the authors based on [1].

Many scientific discussions were made to unveil the impact of economic, social and political spheres on developing energy-efficiency and promoting renewable energy sources. The findings proved the snowballing growth of scientific interest in investigating renewable energy development's economic influence (Fig.2). In could be assumed that in 2014, the number of publications increased by $31 \%$ and stated to rapid growth when the Intergovernmental Panel on Climate Change presented the Fifth Assessment Report on the anthropogenic impact on climate change in 2013.

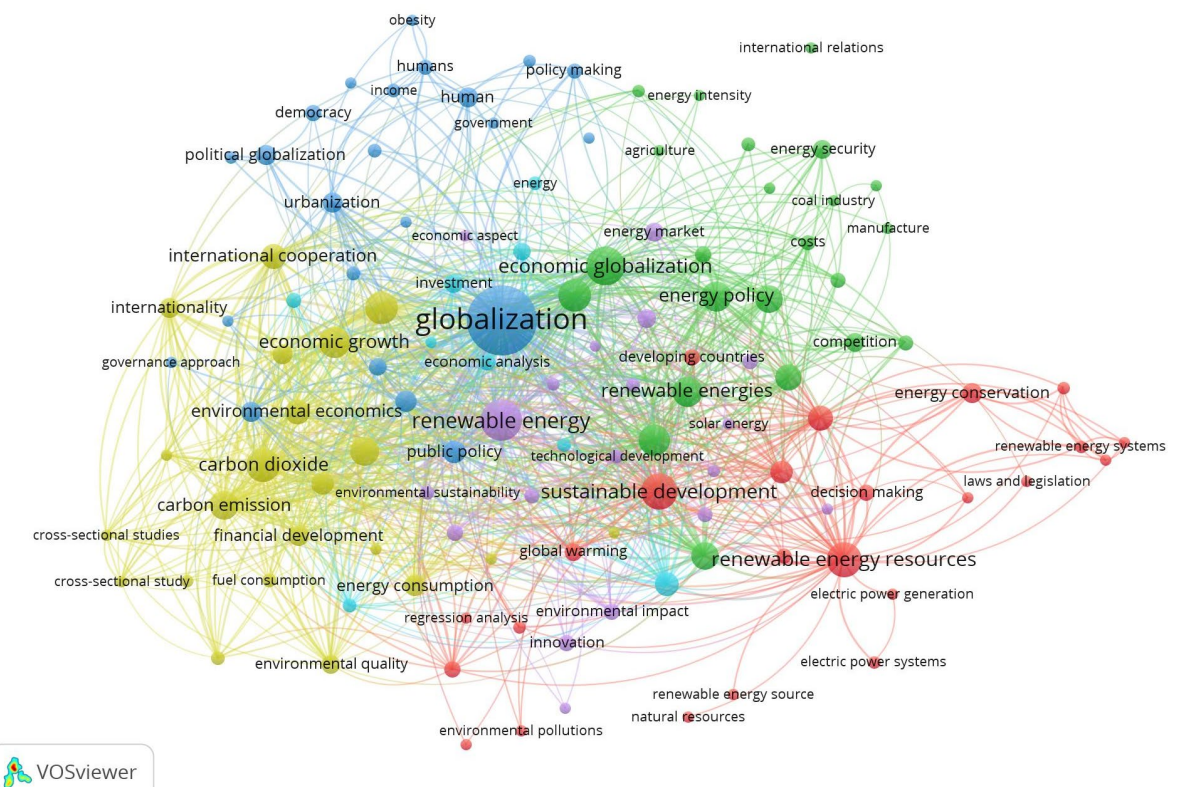

Fig. 3. The visualisation of co-occurrence network map on "renewable energy" and "economic growth", 2000-2020

Source: developed by the authors based on [1].

To find the main directions in publication activity, this study applied the visualisation of similarities method described in the several scientific papers $[3 ; 4 ; 5 ; 6]$. The practical realisation was provided with the VOSviewer software tool. The study sample consisted of 
2000 of the most cited documents published in the high-reliable scientific journals indexed by the Scopus database from 2000 to 2020 .

The findings proved the strong relationship between economic growth and renewable energy. Figure 3 shows the strong link strength between the term "renewable energy" and "economic growth". This couple of terms co-occurred 147 times in the investigated documents published from 2000 to 2020 . The total link strength of the "renewable energy" is higher -833 , while "globalisation" -719 .

Therefore, the network analysis of keyword co-occurrence demonstrates three big clusters which indicate the research direction of analysed documents. The first biggest cluster (blue) consists of 42 terms which demonstrates the scientists' interest in developing the globalisation process. The second cluster (green) shows that scientists devoted a lot of attention to economic growth and economic globalisation in renewable energy consumption (link strength is 79). In turn, the third (purple) and forth (red) clusters allowed concluding that the issues of renewable energy were investigated under economic globalisation (link strength is 39), climate change (link strength is 35), in prospects of political globalisation (link strength is 35), energy efficiency (link strength is 27) and others.

The above analysis showed that research directions such as looking for best energy practices, new methods, innovative technologies, green financing, economic mechanisms etc., in mitigating and adopting against adverse climate are prioritised on the international level to develop renewable energy carbon-free economy. The obtained results indicated that the scientific community has significant progress in investigating the role of economic and political globalisation in developing and extending renewable energy [7-11].

In the studies [13-15] the findings confirmed the linking between economic growth, renewable energy and greenhouse gas emission. The authors noted that green investments boost economic development by renewable energy while decreasing the adverse greenhouse gas emissions [16; 17]. The influence of energy efficiency aspects on economic welfare was considered in the studies [1826].

However, the obtained results showed the scarcity of publications devoted to investigating the impact of determinants of democracy and globalisation processes on renewable energy development [27-33]. In turn, Fig. 4 allowed noticing that growth of democracy (DI) and globalisation level (KOF) provoke energy-efficient development).

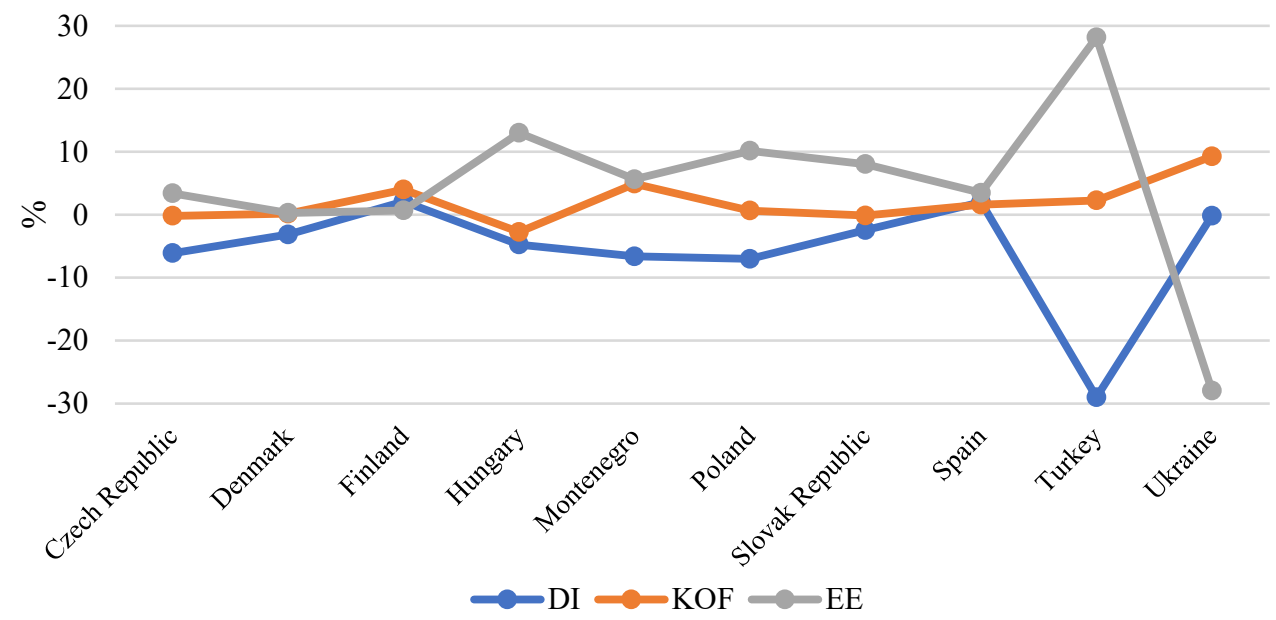

Fig. 4. Changes oEEEE, DI and KOF in 2019 compared to 2012

*Source: developed by the authors based on the data $[34 ; 35 ; 36]$. 
Besides, this research direction is relatively new. The study [38] analyses the impact of democracy and renewable energy on the volume of carbon emission. The authors emphasised that the trade openness, population, economic growth and foreign direct investment forced behind the carbon emissions. However, economic growth could decrease the volume of carbon emission if democracy was accounted for. In the paper [39] the author proposed instruments to accelerate energy transition under political influence. The author indicated that collaboration between government and business in the energy sector promotes economic decarbonisation by increasing the renewable-driven buyers and increasing the number of government energy policy supporters by the corporate renewable buyers.

The paper [40] provides the analysis of policy choices impact on renewable energy development. The authors concluded that the EU membership, federalist political system and the state of the existing energy supply system were the main drivers in renewable energy development. The findings showed that supporting renewable policy in electricity production did not depend on fossil and nuclear energy shares in the economy's national energy supply and $\mathrm{CO} 2$ intensity. In the study [41] the scientists analysed the determinants of adopting climate-relevant policies based on the examples of developing and emerging countries. The authors concluded that the probability of adopting renewable energy policies is higher for more developed counties. Besides, EU membership facilitates renewable policy adoption, while natural endowments for producing renewable energy had less influence on governments to adopt renewable energy policies.

Given the above results, this study investigates the impact of economic and political globalisation on renewable energy for EU countries with different democracy regimes and Ukraine and Turkey as the potential EU candidates.

\section{Materials and methods}

The core hypothesis of the paper was:

H1: The type of political regime, the level of economic and political globalisation influences renewable energy.

For the analysis, the study used the Cobba-Duglas function framework, which explains that total production relates to labour and capital inputs [42-45]. In the papers $[46 ; 47]$ the authors used the modified function (extending the traditional model by the renewable energy and others explanatory variables) to explain the relationships among renewable energy, carbon emissions and gross domestic product. The findings [48; 49] confirmed that globalisation allowed declining the energy demand by spreading green innovations.

Considering it, the study used the modified function (1) where economic and political globalisations were chosen as explanatory variables:

$$
R E=f(K ; L ; G D P ; E G ; P G)
$$

where RE - the share of renewable energy in the final energy consumption; EG - the level of economic globalisation; PG - the level of political globalisation; $\mathrm{K}$ - the gross fixed capital formation; $\mathrm{L}$ - total labour force (people from ages 15 and older who supply labour); GDP - gross domestic products.

The study sample was generated by EU countries with different political regimes involving Ukraine and Turkey (potential EU members). The Economist Intelligence Unit was a source countries' Democracy Indexes for dividing them be three groups (Table 1): Full democracy (Finland, Denmark, Spain), Flawed democracy (Poland, Slovakia, Hungary and the Czech Republic) and Hybrid regime (Montenegro, Turkey and Ukraine). 
Table 1. Countries by regime types (Democracy Index 2020)

\begin{tabular}{|c|c|c|c|}
\hline Country & Regime type & $\begin{array}{c}\text { Country's score } \\
2020\end{array}$ & Description \\
\hline Finland & \multirow{3}{*}{ Full democracy } & 9.2 & \multirow{3}{*}{$\begin{array}{l}\text { Political culture respects and } \\
\text { reinforces civil liberties and } \\
\text { fundamental political freedom. }\end{array}$} \\
\hline Denmark & & 9.15 & \\
\hline Spain & & 8.12 & \\
\hline Czech Republic & \multirow{4}{*}{$\begin{array}{c}\text { Flawed } \\
\text { democracy }\end{array}$} & 7.67 & \multirow{4}{*}{$\begin{array}{l}\text { Elections are fair and } \\
\text { accessible, and fundamental } \\
\text { civil liberties are honoured. } \\
\text { However, political culture is } \\
\text { underdeveloped. }\end{array}$} \\
\hline Slovakia & & 6.97 & \\
\hline Poland & & 6.85 & \\
\hline Hungary & & 6.56 & \\
\hline Montenegro & \multirow{3}{*}{ Hybrid regime } & 5.77 & \multirow{3}{*}{$\begin{array}{l}\text { Government pressure on } \\
\text { political opposition, electoral } \\
\text { frauds, corruption, etc. }\end{array}$} \\
\hline Ukraine & & 5.81 & \\
\hline Turkey & & 4.48 & \\
\hline
\end{tabular}

*Source: compiled by the authors based on the data [34].

The data used in this study were obtained from the Eurostat database (share of renewable energy in final energy consumption), KOF Swiss Economic Institute (KOF Globalization Index and its dimensions), World Data Bank (GDP, Labour force and Gross fixed capital formation) for 2012-2019 years.

Table 2. Variables, denotation, and their meaning for analysis

\begin{tabular}{|c|c|c|c|}
\hline Variables & Denotation & Meaning & Source \\
\hline $\begin{array}{l}\text { Economic } \\
\text { Globalisation }\end{array}$ & $\mathrm{EG}$ & $\begin{array}{l}\text { The economic dimension demonstrates } \\
\text { international trade and business activity } \\
\text { state, trade flows, international } \\
\text { investment, international trading } \\
\text { constraints and taxes, etc. }\end{array}$ & \multirow{2}{*}{$\begin{array}{l}\text { KOF Swiss } \\
\text { Economic } \\
\text { Institute }\end{array}$} \\
\hline $\begin{array}{c}\text { Political } \\
\text { Globalisation }\end{array}$ & PG & $\begin{array}{l}\text { Political dimension characterises } \\
\text { country membership in international } \\
\text { organisations, ratification on } \\
\text { international multilateral agreements, } \\
\text { the number of embassies and other } \\
\text { foreign delegation in the country, etc. }\end{array}$ & \\
\hline $\begin{array}{c}\text { Renewable } \\
\text { energy }\end{array}$ & RE & $\begin{array}{l}\text { The share of renewable energy in the } \\
\text { final energy consumption }\end{array}$ & Eurostat \\
\hline $\begin{array}{l}\text { Gross Domestic } \\
\text { Product }\end{array}$ & GDP & $\begin{array}{l}\text { The sum of value added (differences } \\
\text { between producers' gross output and the } \\
\text { value of intermediate goods and services } \\
\text { consumed in production) from all } \\
\text { producers. }\end{array}$ & \multirow{3}{*}{$\begin{array}{c}\text { World Data } \\
\text { Bank }\end{array}$} \\
\hline Capital & $\mathrm{K}$ & gross fixed capital formation in US\$ & \\
\hline Labour & $\mathrm{L}$ & $\begin{array}{l}\text { total labour force (people from ages } 15 \\
\text { and older who supply labour for the } \\
\text { production of goods and services }\end{array}$ & \\
\hline
\end{tabular}

*Source: compiled by the authors based on $[35 ; 36 ; 37]$.

The descriptive statistic of the data presented in Table 3. All data were in logarithm before calculation. The study used the software EViews for the analysis. 


\begin{tabular}{|c|c|c|c|c|c|c|c|}
\hline \multirow{2}{*}{ Levin, Lin \& Chu } & Statistics & $-1,67$ & $-6,17$ & $-16,13$ & $-5,26$ & $-4,17$ & $-0,32$ \\
\cline { 2 - 9 } & Probability & 0,05 & 0,00 & 0,00 & 0,00 & 0,00 & 0,37 \\
\hline \multirow{2}{*}{ Im, Pesaran and Shin W-stat } & Statistics & 0,95 & $-1,02$ & $-1,86$ & $-0,91$ & $-2,33$ & 0,37 \\
\cline { 2 - 9 } & Probability & 0,83 & 0,15 & 0,03 & 0,18 & 0,00 & 0,65 \\
\hline \multirow{2}{*}{ ADF-Fisher Chi-square } & Statistics & 9,67 & 26,11 & 31,08 & 26,63 & 35,67 & 12,89 \\
\cline { 2 - 9 } & Probability & 0,94 & 0,097 & 0,03 & 0,09 & 0,00 & 0,79 \\
\hline \multirow{2}{*}{ PP-Fisher Chi-square } & Statistics & 17,84 & 8,21 & 20,94 & 5,48 & 47,24 & 20,19 \\
\cline { 2 - 9 } & Probability & 0,47 & 0,97 & 0,28 & 0,99 & 0,00 & 0,32 \\
\hline \multirow{2}{*}{ Tests } & Statistic & \multicolumn{7}{|c|}{ at 1 $\mathbf{1}^{\text {st }}$ difference } \\
& Parameters & \multicolumn{7}{|c|}{} \\
\hline \multirow{2}{*}{ Levin, Lin \& Chu } & Statistics & $-4,39$ & $-4,95$ & $-3,23$ & $-5,43$ & $-3,04$ & $-6,53$ \\
\cline { 2 - 8 } & Probability & 0,00 & 0,00 & 0,00 & 0,00 & 0,00 & 0,00 \\
\hline \multirow{2}{*}{ Pesaran and Shin W-stat } & Statistics & $-1,16$ & $-0,21$ & $-0,64$ & $-0,56$ & 1,66 & $-0,02$ \\
\cline { 2 - 8 } & Probability & 0,00 & 0,00 & 0,00 & 0,00 & 0,00 & 0,00 \\
\hline \multirow{2}{*}{ PP-Fisher Chi-square } & Statistics & 27,02 & 17,08 & 22,33 & 21,13 & 29,16 & 18,59 \\
\cline { 2 - 8 } & Probability & 0,00 & 0,00 & 0,00 & 0,00 & 0,00 & 0,00 \\
\cline { 2 - 8 } & Statistics & 69,65 & 19,21 & 43,01 & 19,51 & 91,22 & 40,84 \\
\cline { 2 - 8 } & Probability & 0,00 & 0,00 & 0,00 & 0,00 & 0,00 & 0,00 \\
\hline
\end{tabular}

Source: developed by the author.

The results of stationarity analysis confirmed that only EG was stationary at the level in all tests. Besides, all variables had become stationarity at the 1st level. The findings allowed rejecting the null hypothesis of non-stationarity at $1 \%$ significance. It allowed testing the cointegration among variables using the Pedroni panel cointegration test.

Table 5. The results of cointegration tests among selected variables for model 1 with economic globalisation

\begin{tabular}{|c|c|c|c|c|c|c|c|}
\hline \multirow{3}{*}{ Test } & \multicolumn{4}{|c|}{ Within-dimension } & \multirow{3}{*}{ Test } & \multicolumn{2}{|c|}{$\begin{array}{l}\text { Between- } \\
\text { dimension }\end{array}$} \\
\hline & \multirow{2}{*}{ Stat. } & \multirow{2}{*}{ Prob. } & \multirow{2}{*}{\multicolumn{2}{|c|}{\begin{tabular}{c|c} 
Stat. & Prob. \\
weighted
\end{tabular}}} & & \multirow{3}{*}{$\begin{array}{l}\text { Stat. } \\
4,10\end{array}$} & \multirow{3}{*}{$\begin{array}{r}\text { Prob. } \\
1,00\end{array}$} \\
\hline & & & & & & & \\
\hline panel v-statistic & 0,05 & 0,48 & $-0,93$ & 0,83 & group rho-statistic & & \\
\hline panel rho-statistic & 2,69 & 1,00 & 2,56 & 0,99 & group PP-statistic & $-6,71$ & $0,00 *$ \\
\hline panel PP-statistic & $-3,50$ & $0,00^{*}$ & $-4,83$ & $0,00 *$ & \multirow{2}{*}{ group ADF-statistic } & \multirow{2}{*}{$-5,38$} & \multirow{2}{*}{$0,01 *$} \\
\hline panel ADF-statistic & $-2,89$ & $0,00 *$ & $-4,79$ & $0,02 *$ & & & \\
\hline
\end{tabular}

Table 6. The results of cointegration tests among selected variables for model 2 with political globalisation

\begin{tabular}{|c|c|c|c|c|c|c|c|}
\hline \multirow{3}{*}{ Test } & \multicolumn{4}{|c|}{ Within-dimension } & \multirow{3}{*}{ Test } & \multicolumn{2}{|c|}{$\begin{array}{r}\text { Between- } \\
\text { dimension }\end{array}$} \\
\hline & \multirow{2}{*}{ Stat. } & \multirow{2}{*}{ Prob. } & Stat. & Prob. & & \multirow[t]{2}{*}{ Stat. } & \multirow{2}{*}{ Prob. } \\
\hline & & & & ted & & & \\
\hline panel v-statistic & $-2,56$ & 0,99 & $-2,32$ & 0,99 & group rho-statistic & 3,9 & 1,0 \\
\hline panel rho-statistic & 2,31 & 0,99 & 2,29 & 0,99 & group PP-statistic & $-5,6$ & $0,0^{*}$ \\
\hline panel PP-statistic & $-1,57$ & $0,00^{*}$ & $-2,79$ & $0,00^{*}$ & group ADF- & 27 & \\
\hline panel ADF-statistic & $-1,45$ & $0,00^{*}$ & $-2,39$ & $0,01^{*}$ & statistic & $-2,7$ & \\
\hline
\end{tabular}

Note: * represents significance at the $1 \%$ level.

Source: developed by the author.

The findings (Table 5 and 6) confirmed the statistical significance at $1 \%$ level for six out of eleven test probabilities. Thus, the hypothesis of non-cointegration among selected 
variables could be rejected. It allowed applicating of the Fully Modified Ordinary Least Square (FMOLS) and Dynamic Ordinary Least Square (DOLS) panel cointegration techniques for checking the long-run relationship among selected variables. The finding of FMOLS and DOLS presents in Table 7.

Table 7. The findings of a long-run relationship among selected variables (FMOLS and DOLS panel cointegration techniques)

\begin{tabular}{|c|c|c|c|c|c|c|c|c|c|c|c|c|c|}
\hline \multirow{5}{*}{ Tests } & \multirow{5}{*}{$\begin{array}{c}\text { Stat. } \\
\text { Param. }\end{array}$} & \multicolumn{12}{|c|}{ Model 1 with political globalisation } \\
\hline & & \multicolumn{12}{|c|}{ Dependent Variables RE } \\
\hline & & \multicolumn{4}{|c|}{ Full democracy } & \multicolumn{4}{|c|}{ Flawed democracy } & \multicolumn{4}{|c|}{ Hybrid regime } \\
\hline & & \multicolumn{12}{|c|}{ Independent Variables } \\
\hline & & $\mathrm{L}$ & $\mathrm{K}$ & PG & GDP & $\mathrm{L}$ & $\mathrm{K}$ & PG & GDP & $\mathrm{L}$ & $\mathrm{K}$ & PG & GDP \\
\hline \multirow{2}{*}{$F$} & Coeff. & 0,79 & 1,2 & $-1,11$ & 1,35 & 1,68 & 0,62 & 0,26 & $-0,25$ & 0,82 & 0,07 & 3,63 & 0,18 \\
\hline & Prob. & 0,46 & $0,00^{*}$ & 0,26 & $0,00^{*}$ & 0,38 & $0,09^{* *}$ & $0,04^{*}$ & 0,60 & $0,00^{*}$ & 0,65 & $0,00^{*}$ & 0,38 \\
\hline \multirow{2}{*}{$\mathrm{D}$} & Coeff. & 0,22 & 1,28 & 0,84 & 1,44 & 0,58 & 0,55 & 0,43 & $-0,39$ & 0,87 & 0,12 & 3,62 & $-0,22$ \\
\hline & Prob. & $0,05^{* *}$ & $0,00^{*}$ & $0,03^{* *}$ & $0,01^{*}$ & $0,01^{\prime}$ & $0,02^{* *}$ & $0,02^{*}$ & 0,44 & $0,03^{* *}$ & 0,75 & $0,01^{*}$ & 0,68 \\
\hline \multirow{2}{*}{ Tests } & \multirow{2}{*}{$\begin{array}{c}\text { Stat. } \\
\text { Param. }\end{array}$} & \multicolumn{12}{|c|}{ Model 2 with economic globalisation } \\
\hline & & $\mathrm{L}$ & $\mathrm{K}$ & EG & GDP & $\mathrm{L}$ & $\mathrm{K}$ & EG & GDP & $\mathrm{L}$ & $\mathrm{K}$ & EG & GDP \\
\hline \multirow[b]{2}{*}{$\mathrm{F}$} & Coeff. & 1,03 & 1,13 & 0,13 & 1,36 & 2,37 & 0,74 & 0,33 & $-0,33$ & 0,18 & 0,24 & 0,54 & 0,46 \\
\hline & Prob. & 0,45 & $0,01^{*}$ & $0,00^{*}$ & $0,01^{*}$ & 0,18 & $0,01^{* *}$ & $0,05^{*}$ & 0,21 & $0,02^{* *}$ & $0,01^{*}$ & $0,03^{* *}$ & $0,04^{* *}$ \\
\hline & Coeff. & 0,39 & 1,19 & 0,12 & 1,38 & 2,28 & 0,72 & 0,3 & $-0,40$ & 0,20 & $-0,68$ & 0,42 & 1,51 \\
\hline & Prob. & 0,82 & $0,02^{* *}$ & $0,06^{* *}$ & $0,03^{*}$ & 0,22 & $0,03^{* * *}$ & $0,04^{*}$ & 0,22 & 0,76 & 0,36 & $0,00^{*}$ & $0,08^{* *}$ \\
\hline
\end{tabular}

Note: * and ** represents significance at the $1 \%$ and $5 \%$ levels; F - FMOLS techniques; D - DOLS techniques

Source: developed by the author

The results of long-run relationship analysis confirmed that for the countries from full democracy the group an increase of $1 \%$ in gross domestic product and capital (in both FMOLS and DOLS panel cointegration techniques), labour and political globalisation (DOLS panel cointegration techniques) lead to increasing renewable energy by $1.35,1.2$, 0.84 and 1.28 , respectively. In the model with economic globalisation, the same indicators gross domestic product, capital and political globalisation had a statistically significant impact on renewable energy at $1 \%$ and $5 \%$.

In the model with political globalisation for the countries with flawed democracy, all variables excluding GDP (DOLS) positively impacted growing renewable energy. Thus, increasing labour, capital and political globalisation allowed increasing the renewable energy by $0.58,0.55,0.43$, respectively. In the model with economic globalisation only two indicators (labour and economic globalisation) were statistically significant at $1 \%$ and $5 \%$.

However, in model 1 for countries with the hybrid regime, an increase of $1 \%$ in political globalisation and labour (in both FMOLS and DOLS panel cointegration techniques) allowed increasing the renewable energy 0.82 and 3.63 (FMOLS), 0.87 and 3.62 (DOLS), respectively and in the model 2 with FMOLS panel cointegration techniques, increasing of all variables by $1 \%$ lead to increasing of renewable energy.

The findings allowed concluding that for countries with the hybrid regime, the changes in political and economic globalisation provided the rapid growth of renewable energy compared with countries from full and flawed democracy.

\section{Conclusions}

Given the traditional economic model, economic growth requires more resource while increasing the adverse environmental impact. The carbon-neutral model of economic development promotes renewable energy demand. However, the aforementioned contradicts 
with principles of sustainable development. Therefore, this paper provided a bibliometric analysis of publication activity to determine the main research directions on the linkage between renewable energy and globalisation process in the countries. Using the VOSviewer software tool allowed visualising the network map of keywords' co-occurrences of the highreliable documents indexed by the Scopus database from 2000 to 2020. The obtained results proved the strong link strength between renewable energy, political and economic globalisations.

In turn, there were visualised three significant clusters that indicate the scientists' interest in 1) developing energy policy toward carbon-neutrality; 2) economic development under the influence of energy consumption, $\mathrm{CO} 2$ emission and energy consumption; 3) considering the relationship between renewable energy development, political and economic globalisation, Herewith, a comprehend analysis of identified research directions showed that exploring the best energy practices, new methods, innovative technologies, green financing, economic mechanisms etc., in mitigating and adopting against adverse climate were prioritised on the international level to develop renewable energy and carbon-free economy.

Thus, the findings confirmed that in countries with different levels of democracy and political regimes, the changes in the core economic parameters (labour, capital and gross domestic product), economic and political globalisations lead to extending renewable energy with different amplitude. Similar findings were obtained in the papers [39-41]. Thus, the increasing of political globalisation by $1 \%$ provoke the growth of renewable energy by 0.84 for full democracy countries (DOLS), 0.43 for flawed democracy (DOLS), 3.62 for the hybrid regime (DOLS). Thus, the countries with the hybrid regime should focus on implementing the mechanism to strengthen political stability and provide political globalisation. Besides, the growth of economic globalisation by $1 \%$ lead to increasing of renewable energy by 0.12 (FMOLS) and 0.13 (DOLS) for full democracy countries, 0.33 (FMOLS) and 0.31 (DOLS) for flawed democracy, 0.42 (FMOLS) and 0.54 (DOLS) for the hybrid regime. The increasing of trade and financial openness allowed improving economic globalisation. It allowed increasing the speed of extending and penetration of renewable energy. The increasing of political and economic globalisation allowed attracting additional green investments and innovation for spreading renewable energy.

\section{Acknowledgements}

This research was funded by the grant from the National Research Foundation of Ukraine "Stochastic modelling of road map for harmonising national and European standards for energy market regulation in the transition to a circular and carbon-free economy" 0120U104807); the Ministry of Education and Science of Ukraine (0121U100468, 0120U102002 and 0121U100469).

\section{References}

1. Scopus database, https://www.scopus.com (2021)

2. Enerdata. Global Energy Statistical Yearbook 2021, https://yearbook.enerdata.net/totalenergy/world-energy-intensity-gdp-data.html (2021)

3. L. Saher, L. Syhyda, O. Korobets, T. Berezianko. E3S Web of Conferences, 234, 00011 (2021)

4. Ya. Us, S. Bilan, T. Pimonenko, R. Seliga, G. Ostasz. Proceedings of the 35th IBIMA Conference: 1-2 April 2020, Seville, Spain (2020)

5. A. Zolkover, V. Terziev. Business Ethics and Leadership, 4(3), 107-118 (2020).

6. H. Eddassi. SocioEconomic Challenges, 4(2), 67-77 (2020) 
7. T. Vasylieva, S. Lieonov, I. Makarenko, N. Sirkovska. Marketing and Innovation Management, 4, 350-357 (2017)

8. M. AUgbaka, A. Awujola, T. Shcherbyna. SocioEconomic Challenges, 3(4), 5-12 (2019)

9. T. Pimonenko, J. Us, D. Leus, S. Fedyna. Bulletin of Sumy State University. Economy Ser, 2, 57-67 (2017)

10. T. Vasilyeva, S., Bilan, K, Bagmet, R. Seliga. Economics and Sociology, 13(1), 271-294 (2020)

11. Y. Kharazishvili, A. Kwilinski, O. Grishnova, H. Dzwigol. Sustainability, 12(21), 8953 (2020)

12. H. Dzwigol, M. Dzwigol-Barosz. Academy of Strategic Management Journal, 19(5), 1$7(2020)$

13. R. Miskiewicz. Polityka Energetyczna, 21(2), 49-62 (2018)

14. K. Djalilov, S. Lyeonov, A. Buriak. Financial Markets and Institutions, 5(4CONT1), 178-187 (2015)

15. A. Kasych, M. Vochozka. Marketing and Management of Innovations, 2, 298-305 (2017)

16. O. Chygryn, A. Rosokhata, O. Rybina, N. Stoyanets. E3S Web of Conferences, 234, $00004(2021)$

17. Y. Samusevych, A. Vysochyna, T. Vasylieva, S. Lyeonov, S. Pokhylko. E3S Web of Conferences, 234, 00012 (2021)

18. H. Dzwigoł, M. Dzwigoł-Barosz, Z. Zhyvko, R. Miskiewicz, H. Pushak. Journal of Security and Sustainability Issues, 8(3), 307-317 (2019)

19. O. Chygryn, Y. Bilan, A. Kwilinski. Marketing and Management of Innovations, 3, 358$370(2020)$

20. T. Pimonenko. Economics and Region. 4(71), 5-15 (2018)

21. D. T. Am. Financial Markets, Institutions and Risks, 3(2), 69-78 (2019)

22. A. El Amri, R. Boutti, S. Oulfarsi, F. Rodhain, B. Bouzahir. Financial Markets, Institutions and Risks, 4(4), 31-44 (2020)

23. He. Shuquan Business Ethics and Leadership, 3(4), 43-48 (2019)

24. E. Jafarzadeh, He. Shuquan. Business Ethics and Leadership, 3(2), 53-62 (2019)

25. H.D. Kaya. SocioEconomic Challenges, 3(3), 5-12 (2019)

26. S. Mahapatra, A. Pandey, B. Narayanan. SocioEconomic Challenges, 4(2), 23-30 (2020)

27. M.A. Khan, A. Kishwar. Financial Markets, Institutions and Risks, 4(2), 108-114 (2020)

28. A. El Amri, R. Boutti, F. Rodhain. Financial Markets, Institutions and Risks, 4(2), 5264 (2020)

29. T. Kurbatova, R. Sidortsov, I. Sotnyk, I., O. Telizhenko, T. Skibina, R. Hynek. Problems and Perspectives in Management, 17(3), 464 (2019)

30. V. Panchenko, Yu. Harust, Ya Us, O. Korobets, V. Pavlyk. Marketing and Management of Innovations, 1, 256-264 (2020)

31. V. Bozhkova, O. Ptashchenko, L. Saher, L. Syhyda. Marketing and Management of Innovations, 1, 73-82 (2018)

32. A. Bonamigo, D. Mendes. Business Ethics and Leadership, 3(4), 66-73. (2019)

33. N. Letunovska, O. Dalechin, K. Bieliaieva. Practical aspects of business planning in the system of investment project implementation. Marketing and Management of Innovations, 3, 226-235 (2017)

34. O. Chygryn. Centre for Studies in European Integration Working Papers Series, (6), 613 (2017)

35. Y. Bilan, T. Vasylieva, S. Lyeonov, I. Tiutiunyk, I. Entrepreneurial Business and Economics Review, 7(2), 27-43 (2019)

36. T. Vasylieva, V. Kasyanenko. Actual Problems of Economics, 144(6), 50-59 (2013)

37. M. Kordos. Marketing and Management of Innovations, 3, 341-353 (2019) 
38. The Economist Intelligence Unit, https://www.eiu.com/n/campaigns/democracy-index$2020(2021)$

39. Eurostat, https://ec.europa.eu/eurostat/databrowser/view/nrg_ind_eff/default/table?lang=en (2021)

40. KOF Globalisation Index, https://kof.ethz.ch/en/forecasts-andindicators/indicators/kof-globalisation-index.html (2021)

41. World Data Bank, https://data.worldbank.org (2021)

42. S. Adams. Journal of Cleaner Production, 118245 (2019)

43. Z. Tzankova. Energy Research and Social Science, 67, 101504 (2020)

44. L. Schaffer, T. Bernauer. Energy Policy, 68, 15-27 (2014)

45. M. Stadelmann, P. Castro. Global Environmental Change, 29, 413-423 (2014)

46. M. E. BildiriciMEE. Biomass Bioenergy, 50, 19-24 (2013)

47. E. Dogan, B. Turkekul. Environ. Sci. Pollut. Res 23, 1203-1213 (2016)

48. C.T. Tugcu. Int. J. Energy Econ. Policy 3, 307 (2013).

49. C. T. Tugcu, I. Ozturk, A. Aslan. Energy Econ, 34, 1942-1950 (2012)

50. K. Saidi, A. Omri. Environmental research, 186, 109567 (2020).

51. D. H. Vo, A. T. Vo, C. M. Ho, H. M. Nguyen. Renewable Energy, 161, 278-292 (2020)

52. J. Baek, Y. Cho, W. W. Koo. Ecol. Econ. 68 (8-9), 2255-2264 (2009)

53. G. Gozgor, M. K. Mahalik, E. Demir, H. Padhan. Energy Policy, 139, 111365 (2020) 